\title{
Title IX in the Technological Age-Challenging Rape Culture and Myths Through Fairer Use of Electronic Communications
}

\author{
Drew Simshaw \\ dsimshaw@elon.edu
}

Follow this and additional works at: https://trace.tennessee.edu/rgsj

Part of the Law Commons

\section{Recommended Citation}

Simshaw, Drew (2017) "Title IX in the Technological Age-Challenging Rape Culture and Myths Through Fairer Use of Electronic Communications," Tennessee Journal of Race, Gender, \& Social Justice: Vol. 6 : Iss. 2 , Article 6.

Available at: https://trace.tennessee.edu/rgsj/vol6/iss2/6

This Article is brought to you for free and open access by Volunteer, Open Access, Library Journals (VOL Journals), published in partnership with The University of Tennessee (UT) University Libraries. This article has been accepted for inclusion in Tennessee Journal of Race, Gender, \& Social Justice by an authorized editor. For more information, please visit https://trace.tennessee.edu/rgsj. 


\section{Title IX in the Technological Age-Challenging Rape Culture and Myths Through Fairer Use of Electronic Communications}

\section{Cover Page Footnote}

Legal Method and Communication Fellow at Elon University School of Law. Former teaching fellow at Georgetown Law's Institute for Public Representation. B.A., University of Washington; J.D., Indiana University Maurer School of Law; LL.M. with distinction, Georgetown Law. Thanks to Meghan Boone and Carrie Goldberg for their always thoughtful discussions on Title IX. Thanks also to the organizers and participants of the Title IX: History, Legacy, and Controversy symposium hosted by the Tennessee Journal of Race, Gender \& Social Justice, especially Nancy Chi Cantalupo, Margaret Drew, Liam Dunn, and Joy Radice. 


\title{
TITLE IX IN THE TECHNOLOGICAL AGE-CHALLENGING RAPE CULTURE AND MYTHS THROUGH FAIRER USE OF ELECTRONIC COMMUNICATIONS
}

\author{
Drew Simshaw*
}

\section{Table of Contents}

I. INTRODUCTION.

II. A CLOSER LOOK AT MISSOULA - A CASE STUDY OF DISTORTION

OF ELECTRONIC COMMUNICATION EVIDENCE WITH RAPE MYTHS .... 277

III. TITLE IX - A DIFFERENT SETTING, WITH DIFFERENT GOALS, CHALLENGES, AND OPPORTUNITIES.

IV. CAMPUSES HAVE ACCESS TO MORE ELECTRONIC COMMUNICATIONS THAT COULD HELP PAINT A MORE COMPLETE PICTURE OF EVENTS

V. LEVERAGE BETTER-SITUATED DECISION MAKERS OPERATING UNDER A LOWER BURDEN OF PROOF .........................................................290

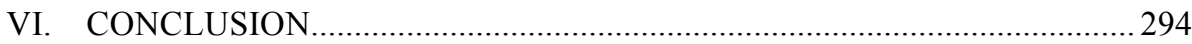

\section{INTRODUCTION}

Electronic communications are critical pieces of evidence in both civil and criminal legal proceedings. ${ }^{1}$ This is especially so in cases where decision makers are charged with determining the truthfulness of conflicting accounts of events. One area of the law where this frequently occurs is cases involving sexual assault, where a survivor's account of lack of consent to sex can be challenged by an alleged

\footnotetext{
${ }^{*}$ Legal Method and Communication Fellow at Elon University School of Law. Former teaching fellow at Georgetown Law's Institute for Public Representation. B.A., University of Washington; J.D., Indiana University Maurer School of Law; LL.M. with distinction, Georgetown Law. Thanks to Meghan Boone and Carrie Goldberg for their always thoughtful discussions on Title IX. Thanks also to the organizers and participants of the Title IX: History, Legacy, and Controversy symposium hosted by the Tennessee Journal of Race, Gender \& Social Justice, especially Nancy Chi Cantalupo, Margaret Drew, Liam Dunn, and Joy Radice. ${ }^{1}$ See, e.g., Zachary G. Newman \& Anthony Ellis, The Reliability, Admissibility, and Power of Electronic Evidence, AM BAR ASS'N (Jan. 25, 2011), https://apps.americanbar.org/litigation/committees/trialevidence/articles/012511electronic-evidence.html (describing how the "impact of . . emails can have a longlasting effect on the court or jurors").
} 
perpetrator. ${ }^{2}$ Electronic communications have tremendous potential to aid decision makers in this task because these communications offer certain insights into the unfolding of events that were not available before communications were "datafied" to such an extent. ${ }^{3}$ In theory, certain electronic communications documented during the time leading up to an assault, during the assault itself, or after the assault, could help corroborate the survivor's account, including whether or not there was consent. However, these electronic communications also serve as a window into psychological trauma responses and generational communication habits that are frequently misunderstood by investigators, decision makers, and the public. As a result, electronic communications can also be used to distort events - and particularly the behavior of survivors in response to the trauma-through the perpetuation of rape myths that inhibit justice.

For example, consider a case in which a sexual assault survivor sends a text message immediately after the assault to a friend which reads, "OMG, I think I might have just gotten raped." message has several hallmarks of reliable and probative evidence for determining whether the sex was consensual, in the event that consent is disputed. The communication is in electronic form, so its authenticity - including the identity of the author and time it was sentcan be verified to a high degree of certainty by witnesses, the phone's metadata, or the wireless service provider. ${ }^{5}$ The communication was documented contemporaneously with the immediate aftermath of the events in question, so the statement, as a matter of reliability, is more likely to be accurate and truthful than if it was communicated later. ${ }^{6}$

\footnotetext{
${ }^{2}$ See, e.g., Bernice Yeung, A Problem of Evidence, Huffington Post (Sep. 14, 2013, 2:46 PM), http://www.huffingtonpost.com/bernice-yeung/sexual-assaultrape_b_3917144.html ("Prosecutors say they have to be strategic in the cases they take, and the he-said, she-said nature of rape and sexual assault cases present significant challenges."); Rebecca Leitman Veidlinger, How to Improve Prosecutions of Campus Sexual Assault, THE ProseCUTOR, June 2014 at 18 (describing the importance of "gather[ing] corroborating evidence of all other aspects of the encounter to confirm exactly what happened in the pejorative 'he saidshe said' case").

${ }^{3}$ VikTOR MAYer-SchÖnberger \& KenNeth Cukier, Big Data: A ReVolution That Will Transform How We LiVe, Work, AND THINK, 76-78 (2013) (discussing the term "Datafication," which they define as the act of transforming something into "a quantified format so it can be tabulated and analyzed").

${ }^{4}$ See infra p. 4 and note 9.

${ }^{5}$ See Hon. Paul W. Grimm et al., Authenticating Digital Evidence, 69 BAYLOR L. REV. 1, 19-22 (2017).

${ }^{6}$ See FED. R. EVID. 803 (excluding from the hearsay rule statements "describing or explaining an event or condition, made while or immediately after the declarant perceived it" because "substantial contemporaneity of event and statement negate the likelihood of deliberate or conscious misrepresentation").
} 
Finally, the message demonstrates that in the moment, as a matter of fact, the survivor did not believe the sex to have been consensual. ${ }^{7}$

Indeed, this was an actual message sent by a student at the University of Montana after she was allegedly raped by a member of the school's football team. Author John Krakauer recounts the heavily publicized events and the trial of the football player, Jordan Johnson, in his book Missoula ${ }^{8}$ assigning the pseudonym Cecilia Washburn to the survivor. ${ }^{9}$ The degree to which this case documents the role of electronic communications in sexual assault cases makes it a valuable case study for analyzing how such communications affect the presentation of a case and influence juries, as well as the ways in which such communications can be used to discredit survivors of sexual assault through the perpetuation of rape myths.

Part II introduces this case study and examines how electronic communications can be used in criminal sexual assault cases. Part III contrasts the criminal setting with the parallel Title IX setting, analyzing the different goals, challenges, and opportunities present in each. Part IV argues that, in light of these differences, higher education institutions have access to a greater number of electronic communications that could help paint a more complete and factually and scientifically accurate picture of events. Part V identifies the ways in which the Title IX setting can leverage better-suited decision makers operating under a lower burden of proof to make fairer use of electronic communications in sexual assault cases. Part VI concludes that one reason to retain Title IX's lower standard is that it allows more room for some degree of the inevitable uncertainty that accompanies new technologies, in a setting where those technologies are adopted at high rates. This analysis captures only a small portion of the efforts needed to combat broader rape culture, and depends on continued Title IX enforcement and oversight in the face of the Trump Administrations efforts to weaken federal guidance and oversight.

\section{A CLOSER LOOK AT MISSOULA - A CASE STUDY OF DISTORTION OF ELECTRONIC COMMUNICATION EVIDENCE WITH RAPE MYTHS}

Despite the text message and other evidence indicating that the sex between Johnson and Washburn was not consensual, Johnson was

\footnotetext{
${ }^{7} I d$.

${ }^{8}$ Jon Krakauer, Missoula: Rape and the Justice System in a College Town (2015).

${ }^{9} I d$. at 133 . For consistency, this essay will reference the survivor by the same pseudonym.
} 
found not guilty by a jury. ${ }^{10}$ The reason why, might surprise some observers. One might think that the word "might" in the statement, "I think I might have just gotten raped," could have led jurors to believe there was doubt in the mind of Washburn concerning whether the sex that had just occurred was nonconsensual, and that this doubt would therefore create reasonable doubt in the minds of the jury as to whether a crime occurred. ${ }^{11}$ Indeed, this might have factored into the decision of some jurors. However, according to one juror interviewed by Krakauer, one major factor that led the jury to doubt Washburn's claim that she did not consent, was not the content of the text message at all. Rather, the jury was struck by the fact that an electronic message was sent at all during the time immediately following the alleged assault. ${ }^{12}$ Krakauer quotes the juror's recounting that members of the jury "were baffled about why '[Washburn] didn't scream or run to her friend outside the bedroom, instead of taking the time to write a message on her phone." 13 This is one example of the ways in which an electronic communication can be used to perpetuate a rape myth in order to discredit a survivor's claim that there was no consent. In this case, the myth was that someone who does not kick and scream and resist during an assault, must have consented to the intercourse,${ }^{14}$ in which case there would be no crime.

Engaging in familiar social behavior, such as sending a text, after trauma is not unusual, and in fact is common. ${ }^{15}$ David Lisak, Harvard clinical psychologist and one of the nation's foremost experts on rape and its associated trauma, ${ }^{16}$ testified at Johnson's trial to explain

\footnotetext{
${ }^{10}$ Id. at 299; Gwen Florio, Jordan Johnson Found Not Guilty of Rape, THE Missoulian (Mar. 1, 2013), http://missoulian.com/news/local/jordan-johnsonfound-not-guilty-of-rape/article_797ee060-82ba-11e2-b4cb-001a4bcf887a.html.

${ }^{11}$ See infra Section II, for explanation of confusion and doubt that are common following a trauma like sexual assault.

${ }^{12}$ KRAKAUER, supra note 9, at 304.

${ }^{13} I d$.

${ }^{14}$ See, e.g., Morrison Torrey, When Will We Be Believed? Rape Myths and the Idea of A Fair Trial in Rape Prosecutions, 24 U.C. DAVIS L. REV. 1013, 1071 n.93 (1991) (describing sexual violence in the media as portraying that "despite initial resistance, the female victim secretly desires the abusive treatment and eventually derives pleasure from it," whereas "male victims usually 'fight back'"); Kaarin Long, Caroline Palmer, \& Sara G. Thome, A Distinction Without A Difference: Why the Minnesota Supreme Court Should Overrule Its Precedent Precluding the Admission of Helpful Expert Testimony in Adult Victim Sexual Assault Cases, 31 HAMLINE J. PUB. L. \& POL'Y 569, 582 (2010) (describing "particularly troublesome [rape] myths," including that "[v]ictims vigorously resist being attacked").

${ }^{15}$ See, e.g., Long, Palmer, \& Thome, supra note 15, at 587 ("During this complicated post-assault period of reflection, victims often 'maintain the status quo'....").

${ }^{16}$ See DAVID LISAK, http://www.davidlisak.com/ (last visited Sept. 15, 2017).
} 
to the jury that Washburn's behavior was typical of trauma survivors. ${ }^{17}$ And indeed, the juror interviewed by Krakauer, for one, recognized that "texting was Ms. Washburn's usual form of communication," and that "[t] exting what had happened to her made sense."18 The jury as a whole was not convinced by Lisak's expert testimony concerning Washburn's texts. ${ }^{19}$ This suggests that even if a decision maker accepts the science behind trauma response, that decision maker might nevertheless still find against the survivor if the decision maker does not understand what constitutes "familiar social behavior" for a younger generation, including frequent-even habitual or compulsive ${ }^{20}$-messaging through text and social media platforms. This case study reflects the generational, ${ }^{21}$ social, and socioeconomic disparities between collegeaged students and the on-average older populations that serve as decision makers in cases in which they are involved. In the context of sexual assault cases, this case study suggests that these disparities can make the decision maker more susceptible to succumbing to rape myths because the myths are an easier explanation of what transpired than an explanation involving science and technology. This susceptibility can be exacerbated by unequal access to education and the underlying technology used to communicate the messages used as evidence.

Washburn's text message was not the only electronic communication used during the Johnson case by defense attorneys to discredit Washburn with rape myths. The defense also used a Facebook message sent by Washburn to a friend eighteen days after the incident. ${ }^{22}$ In the message, Washburn makes statements that, like the text message, exhibit common responses to trauma, including guilt, self-doubt, and confusion. ${ }^{23}$ During questioning at trial regarding the message, the

\footnotetext{
${ }^{17}$ See KRAKAUER, supra note 9, at 233.

${ }^{18} I d$. at 304 . Despite the juror's view on this specific point, she still did not believe the prosecution met its burden of proof. Id.

${ }^{19}$ See infra Section V, for discussion of the Johnson defense counsel's discrediting of Lisak.

${ }^{20}$ See, e.g., Roni Caryn Rabin, Compulsive Texting Takes Toll on Teenagers, N. Y. TiMES (Oct. 12, 2015), https://well.blogs.nytimes.com/2015/10/12/compulsivetexting-takes-toll-on-teenagers/.

${ }^{21}$ Jane Wakefield, The Generation that Tech Forgot, BBC (May 25, 2017), http://www.bbc.com/news/technology-32511489 (questioning whether "older people want any of this [technology] when many have not got to grips with the more basic technology most of the younger generation take for granted").

${ }^{22}$ KRAKAUER, supra note 9, at 248.

${ }^{23}$ See Christopher Emrich, The Playboy Defense in Philadelphia: How Pennsylvania Continues to Thwart Fair and Effective Sexual Assault Prosecutions by Refusing to Admit Expert Testimony About Rape Trauma Syndrome, 6 RUTGERS J.L. \& PUB. POL'Y 891, 911 (2009) (noting common responses include "humiliation, degradation, guilt, shame, and embarrassment to self-blame, anger and revenge." (citing ANN
} 
defense attorney quoted a portion of the message in which Washburn states, "And now I keep thinking, well, maybe I did want it, and that's why I didn't punch him or kick him or bite him," without initially offering that she later also said, "It's all ridiculous because I know I didn't ask for this." ${ }^{24}$ In front of the jury, the defense was able to get Washburn to agree with the phrase "all you can think about is how you could have prevented it . . . [a]nd how you should have tried harder." 25 $\mathrm{He}$ also singled out several statements from the message which he claimed suggested she sent "mixed signals" regarding consent, ${ }^{26}$ including portions of the message where Washburn said "[i]t just seems like the more and more this drags on, the more and more I feel guilty about it," and "[the situation] makes me feel like I lied," and "[m]aybe my other friends will think I lied about it, or what if it really is my fault .... [i]t's so frustrating. ${ }^{, 27}$ Although these reactions are normal, ${ }^{28}$ it is only recently that they have been documented so thoroughly in text and social media messages and made available to juries.

The practice of resorting to rape myths as part of a defense strategy is neither new nor uncommon. ${ }^{29}$ High profile cases like Johnson's are no exception. ${ }^{30}$ However, the ease with which attorneys can access documentation of trauma response in order to seize on these opportunities, has yet to be thoroughly explored in legal literature. Whereas in the past, these responses to trauma might transpire as purely internal processes within a survivor's own mind, or through face-to-face conversations that would not be recorded or documented, today, it is not at all uncommon for survivors to share these thoughts in electronic messages with a trusted friend or family member. ${ }^{31}$ Although in the aftermath of an assault, some survivors might be reluctant to hand over copies of their electronic communications out of general concern for privacy, others might be eager to share such communications in order to demonstrate that they have nothing to hide, and to help corroborate

WOLBERT BuRgess \& LyNDA LyTLE HOLMSTROM, RAPE: ViCTIMS OF CRISIS, 39 (1975))).

${ }^{24}$ KRAKAUER, supra note 9, at 248.

${ }^{25} \mathrm{Id}$.

${ }^{26} \mathrm{Id}$.

${ }^{27} I d$. at $248-49$.

${ }^{28} \mathrm{Id}$. at 254.

${ }^{29}$ See Caroline Heldman, Bill Cosby's Legal Defense was a Case Study in Rape Culture, Vox, (June 13, 2017), https://www.vox.com/firstperson/2017/6/13/15793220/bill-cosby-trial-rape-culture (quoting Kamilah Willingham, "These myths and the norms they evoke are employed routinely to discredit sexual assault survivors. Rapists' defense attorneys know they can rely on juries' susceptibility to these unexamined myths, and more often than not, they are successful.").

${ }^{30} I d$.

${ }^{31}$ See infra Section II, for discussion on maintaining normalcy after an assault. 
their version of the events. ${ }^{32}$ The potential for misuse of certain electronic communications might not be immediately apparent to a survivor. ${ }^{33}$

In the Johnson case, the defense's attempts to discredit Washburn by distorting her electronic communications, worked. ${ }^{34}$ Such practices raise a host of troubling issues within the criminal justice system. This essay examines, within the context of the Missoula case study, two particularly significant reasons why such manipulation of electronic communication is possible, especially when the case involves college students. The first, as indicated above, is that some decision makers do not understand, do not believe, or are not open to considering the science behind survivor responses to trauma-including a desire to maintain normalcy - which are increasingly visible due to electronic communications. The second reason is that some decision makers do not understand the way college students communicate through technology, and therefore do not understand the underlying normalcy that trauma survivors try to maintain vis-à-vis that technology following an attack. Indeed, in the Johnson case, Krakauer recounted that the juror he interviewed

Believed that Johnson probably benefitted from the fact that several members of the jury were of a sufficiently advanced age to be mystified by the behavior of modern college students, for whom text messages are the default mode of communicating with one another. "Texting was a foreign concept" to some of her fellow jurors, [she] observed, so the significance of the text Washburn sent to [her friend] saying 'Omg, I think I might have just gotten raped' might well have been lost on them. ${ }^{35}$

Concrete solutions to overcoming these challenges within the criminal justice system and throughout society is beyond the scope of this paper. Such solutions will require attention to a wide array of issues pertaining to criminal investigations and criminal trial procedures, possibly including the rules of evidence regarding admissibility of electronic

\footnotetext{
${ }^{32}$ See infra Section IV, for example of a case in which a survivor allowed police to download all her text messages. See also supra note 30 and accompanying text, for example of privacy concerns in the Title IX setting and the need for "victim's attorneys" to navigate these considerations.

${ }^{33}$ See Kelly Alison Behre, Ensuring Choice and Voice for Campus Sexual Assault Victims: A Call for Victims' Attorneys, 65 DRAKE L. REV. 293, 302-03 (2017) (discussing the need for "victim's attorneys" as early as initial campus investigations to help with issues like privacy and handing over electronic communications).

${ }^{34}$ KRAKAUER, supra note 9, at 299.

${ }^{35}$ KRAKAUER, supra note 9, at 304.
} 
communications and expert testimony, ${ }^{36}$ jury instructions, and even rules of professional responsibility concerning candor toward the tribunal. ${ }^{37}$ Efforts to ensure that electronic communications are discovered and presented both fairly and effectively in sexual assault cases will also require interdisciplinary efforts to ensure that scientific evidence - when allowed - is credibly, persuasively, and effectively presented to juries. This might also include efforts to more widely educate the public at large about the science of survivor trauma, along with rape culture in general, as well as understanding technology and the way college students use it. All of these solutions will be difficult without closing the "digital divide" 38 that prevents many Americans from accessing, and therefore understanding, technology.

Next, this essay aims to add an additional dimension to these efforts by identifying and analyzing several challenges and opportunities in the parallel setting of investigations into sexual assault undertaken by colleges and universities pursuant to Title IX. It identifies several structural and procedural differences from the criminal system that could enable progress toward more fair and effective use of electronic communications, which could help larger efforts to combat rape culture and sexual assault in the criminal justice system and throughout society.

\section{TITLE IX - A DIFFERENT SETTING, WITH DIFFERENT GOALS, CHALLENGES, AND OPPORTUNITIES}

Although Title IX investigations concern the same underlying sexual assaults and have some investigatory overlap with criminal investigations, ${ }^{39}$ these investigations and proceedings serve very different purposes with different goals, which are important to consider when conducting a comparative analysis. Criminal prosecutions of sexual assault, like prosecution against all crimes, are state efforts, on behalf of a state's citizens, to enforce criminal statutes that result in the

\footnotetext{
${ }^{36}$ See, e.g., Long, Palmer \& Thome, supra note 15, at 582 (2010) ("With rape myth acceptance so prevalent, general expert testimony should be allowed to help jurors more fairly evaluate victim credibility.”).

${ }^{37}$ See Model Rules of Prof'L Conduct r. 3.3 (Am. Bar Ass'N).

${ }^{38}$ See, e.g., Cecilia Kang, The Challenges of Closing the Digital Divide, N. Y. TIMES (June 7, 2016), https://www.nytimes.com/2016/06/09/technology/the-challenges-ofclosing-the-digital-divide.html.

${ }^{39}$ See Veidlinger, supra note 3 , at 18 (explaining that like criminal investigators, "schools are interviewing victims, witnesses and perpetrators; obtaining evidence such as texts and emails; and examining the entire incident with their own critical eyes and ultimately rendering judgment on whether the evidence supports the allegation of sexual assault. This parallel work has the potential to significantly impact the criminal case, in both positive and negative ways.").
} 
deprivation of the liberty of convicted offenders for the good of the public. ${ }^{40}$ Title IX investigations, on the other hand, have served to further Title IX's anti-discrimination goals by placing obligations on schools to respond to allegations of sexual assault in a way that ensures students are not deprived of equal access to the benefits of education. ${ }^{41}$ As such, Title IX's procedures, as outlined in the statute ${ }^{42}$ and articulated in the Department of Education Office of Civil Rights 2011 "Dear Colleague Letter," through investigations and/or hearings, to ensure the safety of students and their ability to receive an equal education. ${ }^{44}$

The process of fulfilling these obligations has changed over time, but, as Deborah L. Brake acknowledges, "the Supreme Court laid the groundwork for Title IX's framework for sexual assault more than a decade before OCR issued its 2011 DCL . ..."45 Today, institutions' responses to sexual assault on campus play a critical role in advancing the broader goals of Title IX. As Brake explains, "Securing Title IX's continued enforcement in the area of campus sexual assault is important not just because sexual assault involves harms to the persons subjected to unwanted sexual contact, but because it has consequences for women's access to power and leadership." ${ }^{, 46}$ This section examines the ways in which electronic communications affect these investigations, as well as how these investigations are situated within, and how they can impact, broader efforts to combat sexual assault.

There are several notable characteristics of the Title IX setting that differentiate it from the criminal setting. Campus investigatory

\footnotetext{
${ }^{40}$ See AmERICAN BAR Association, Criminal Justice Standards: Prosecution Function, Standard 3-1.2.

${ }^{41}$ See Russlynn Ali, Dear Colleague Letter, U.S. DeP'T OF EDUC., OfF. FOR C.R. 3 (Apr. 4, 2011), https://www2.ed.gov/about/offices/list/ocr/letters/colleague 201104.pdf [hereinafter 2011 Dear Colleague Letter] ("[W]hen a student sexually harasses another student, the harassing conduct creates a hostile environment if the conduct is sufficiently serious that it interferes with or limits a student's ability to participate in or benefit from the school's program."); see generally, Deborah L. Brake, Back to Basics: Excavating the Sex Discrimination Roots of Campus Sexual Assault, 6.1 TenN. J. RACE, Gender \& SOC. Just. 7.

4234 C.F.R. $\S 106$.

${ }^{43} 2011$ Dear Colleague Letter. Although the 2011 Dear Colleague Letter was revoked by the Trump Administration in September, 2017, institutions are expected to largely retain their Obama-era procedures until new formal guidance or rules are issued. See Nick Anderson, Trump Administration Rescinds Obama-era Guidance on Campus Sexual Assault, WASH. Post (Sep. 22, 2017),

https://www.washingtonpost.com/local/education/trump-administration-rescindsobama-era-guidance-on-campus-sexual-assault/2017/09/22/43c5c8fa-9faa-11e 78ea1-ed975285475e_story.html?utm term $=.280088467 \mathrm{~b} 59$.

${ }^{44} I d$.

${ }^{45}$ Brake, supra note 42 , at 21.

${ }^{46}$ Brake, supra note 42 , at 15 .
} 
processes yield greater access to electronic communications that have the potential to paint a more complete picture of the events than in the criminal setting. ${ }^{47}$ Campuses also typically have less engaged advocates, as well as decision makers that exclude - and are isolated from-members of the non-campus community at large. ${ }^{48}$ Finally, Title IX proceedings operate under a lower standard of proof that allows for adaption to emerging trauma science and evolving uses of communications technology. ${ }^{49}$

Identifying these differences is not meant to suggest that the criminal system's rules, norms, and goals are wrong, or that those of the Title IX system are right. The different purposes and goals identified above warrant differences in each setting. ${ }^{50}$ Nor does this analysis suggest that either system is perfect within its own setting and in light of its respective goals. Rather, in the context of electronic communications, these differences warrant a separate initial analysis addressing the unique challenges and opportunities on campus.

Notably, this approach flips the script that has dominated the discourse surrounding Title IX and sexual assault, which has heavily focused on the ways in which the criminal justice system does or should influence the Title IX setting. For example, many argue that Title IX investigations should be required to use the "beyond a reasonable doubt" standard utilized by the criminal system, as opposed to the "preponderance of the evidence" standard advocated for by the Obama Administration in its 2011 Dear Colleague Letter. ${ }^{51}$ Instead, this essay identifies several ways in which the Title IX setting, if it overcomes several identified challenges, could influence the criminal setting, including by funneling into the criminal setting a greater number of electronic communications that present a more complete picture of events.

It is important to recognize that this analysis of Title IX is conducted amidst a backdrop in which institutions of higher education are constantly battling the broader rape culture within their walls ${ }^{52}-$ and all too often are doing so inadequately. ${ }^{53}$ Although this essay

\footnotetext{
${ }^{47}$ See infra Section III.

${ }^{48}$ See infra Section III.

${ }^{49}$ See infra Section III.

${ }^{50}$ See Veidlinger, supra note 3, at 8.

${ }^{51}$ See, e.g., REPUBLICAN PARTY PLATFORM 2016, 35, https://prod-cdnstatic.gop.com/media/documents/DRAFT_12_FINAL[1]-ben_1468872234.pdf.

${ }^{52}$ Brake, supra note 42 , at 30 ("Social science research situates sexual assault as a product of the cultures and structures of the institutions in which it occurs."). (citing Peggy Reeves Sanday, The Socio-Cultural Context of Rape: A Cross-Cultural Study, 37 J. SOC. ISSUES 5 (1981)).

${ }^{53}$ See, e.g., Tyler Kingkade, There Are Far More Title IX Investigations of Colleges Than Most People Know, Huffington Post (Jun. 16, 2016),
} 
identifies opportunities within the Title IX setting to combat rape myths through fairer use of electronic communications, it is only a small piece of broader efforts to ensure that school faculty, administrators, and Title IX coordinators do not exacerbate the culture that has created and continues to reinforce rape myths. ${ }^{54}$ Indeed, the predominant presence of rape myths in the higher education setting is in part what necessitated Title IX in the first place, and what demands its continued vigilance going forward. Oversight of institutions' responses to sexual assault and a commitment to the law's broader goals is imperative to these efforts.

The very rape myths and peer norms that underlie sexual assault as a social practice . . . find purchase in the common responses that excuse and minimize sexual assault when it occurs. Without the kinds of specific obligations the Title IX framework places on institutions for handling sexual assault charges, gender scripts and rape myths would have full rein to undermine complainants' credibility and mitigate empathy for their experiences of harm. ${ }^{55}$

Any progress with regard to using insight from electronic communications to corroborate accounts and dispel rape myths, will require some degree of changing this reality. As the following section demonstrates, progress in this regard in the Title IX setting could help inform the criminal setting and society at large. Recognizing several distinct characteristics of the Title IX setting is imperative.

\section{CAMPUSES HAVE ACCESS TO MORE ELECTRONIC COMMUNICATIONS THAT COULD HELP PAINT A MORE COMPLETE PICTURE OF EVENTS}

The informal setting of campus investigations and hearings enables higher education institutions to access more electronic communications from not only survivors who report sexual assault, but also alleged perpetrators, witnesses, and others. ${ }^{56}$ Because these institutions operate under processes developed during the Obama Administrations, when they were required to act immediately in

\footnotetext{
http://www.huffingtonpost.com/entry/title-ix-investigations-sexualharassment_us_575f4b0ee4b053d433061b3d.

${ }^{54}$ Brake, supra note 42, at 33.

${ }^{55}$ Brake, supra note 42 , at 9 .

${ }^{56}$ Veidlinger, supra note 3, at 20.
} 
response to reports of sexual assault, ${ }^{57}$ they gain access to these communications before investigators in the criminal justice system ${ }^{58}$ (if the assault is even reported to police), and when there has been less time to tamper with or destroy them. ${ }^{59}$ Under these circumstances, these institutions are in a position to paint a more complete picture of the events in question, making it harder to fixate upon individual communications of the survivor in a way that makes them more susceptible to rape myths. ${ }^{60}$

Although institutions carry out Title IX investigations in different ways, they are foundationally less formal than the procedures in the criminal setting. ${ }^{61}$ In the criminal setting, communications are typically initially requested by a police officer, collected later pursuant to a warrant, or eventually subpoenaed. From a student perspective, requests in the Title IX setting are far less formal and intimidating. ${ }^{62}$ As Rebecca Leitman Veidlinger observes from her experience in both settings, first as a sex crimes prosecutor, then as a Title IX investigator, in campus investigations, "both the accusing and the accused students often freely provide universities with relevant texts and emails. ${ }^{, 63}$ Even seemingly innocuous electronic communications can be helpful in "hesaid-she-said" cases, and are essential to completing the full picture. Again, the Missoula case study is a helpful illustration of some of these points.

Text messages from the Title IX investigation that preceded Jordan Johnson's criminal case were used to help determine whether he or Washburn was more likely telling the truth. ${ }^{64}$ A comprehensive review of these communications revealed that several text messages sent by Johnson contradicted parts of the story he had told campus

\footnotetext{
${ }^{57}$ See 2011 Dear Colleague Letter (describing “schools' responsibility to take immediate and effective steps to end sexual harassment and sexual violence"); OFFICE OF CIVIL Rights, REVISED SEXUAL HARASSMENT GUIDANCE: HARASSMENT OF Students By School EMPloyees, Other StUdents, or Third PARTIES, Title IX Section $\mathrm{V}(\mathrm{B})(2)$.

${ }^{58}$ Veidlinger, supra note 3, at 19 ("[I]n a typical situation, the university investigator is reaching out to the parties involved within days after learning of the allegation for interviews, possibly before law enforcement speaks to the parties.").

${ }^{59}$ For example, in the Missoula case, Johnson deleted his text messages before police could ask for them. See infra Section IV.

${ }^{60}$ Veidlinger, supra note 3, at 20.

${ }^{61} \mathrm{Id}$. ("The university investigative process bears little resemblance to police station interrogations ....").

${ }^{62} \mathrm{Id}$. ("When accused students are contacted by a university administrator regarding an incident, they are often very willing to talk .... [Whereas with police] suspects might feel threatened, quickly seek a lawyer, and refuse to talk[.] Title IX investigators conduct more low-pressure interviews in university offices....”). ${ }^{63} \mathrm{Id}$.

${ }^{64}$ See infra Section III, for discussion of preponderance of the evidence standard.
} 
investigators. The dean of students in his decision letter to Johnson cited these text messages as central to his decision against Johnson, explaining to Johnson that, "Contrary to your repeated assertions, text messages between you and the victim prove you and the victim were more than mere acquaintances," and, with regard to "[y]our assertion that you and the victim had jointly initiated getting together the night of the rape; a copy of your text messages to the victim clearly proves you initiated the meeting. ..." ${ }^{65}$ This, along with other evidence, led to a ruling that expelled Johnson, for the time being, from the university. ${ }^{66}$

Not only are these electronic communications helpful in a school's internal investigation, they are communications that might never have otherwise come to light in the criminal justice system. ${ }^{67}$ Most survivors do not report being sexually assaulted to the police ${ }^{68}$ If they do, investigations by police are not always thorough. Even if they are thorough, the communications might not be available by the time the investigation is initiated. For example, in the investigation into the criminal case against Johnson, he had deleted text messages on his phone that were from the time of the assault before police could ask for them. ${ }^{69}$ Because six months passed before Washburn reported the assault to the police, Johnson's cell phone carrier had also deleted the messages by the time police sought access. ${ }^{70}$

Even if highly probative electronic communications are sought and gathered by police and turned over to the prosecutor, the prosecutor might nevertheless decline to bring a case. For example, in another University of Montana case, a survivor's friend texted to the survivor,

${ }^{65}$ KRAKAUER, supra note 9, at 182 (citing March 27 letter from University of Montana Dean of Students Charles Couture to Jordan Johnson).

${ }^{66}$ After political pressure, Johnson's expulsion was overturned after review by the Montana commissioner of higher education and Board of Regents. KRAKAUER, supra note 9 , at 185 . Because of the criminal investigation, he was not allowed to play on the football team after being reinstated. $I d$.

${ }^{67}$ See Veidlinger, supra note 3, at 20 (describing emails and texts as evidence that is often available in the Title IX setting, but "that prosecutors may not even know exists and that can be more difficult to get later by law enforcement"). See infra Section IV, for discussion of MOUs and information sharing between criminal and campus investigators.

68 "Rape is the most under-reported crime; $63 \%$ of sexual assaults are not reported to police." National Sexual Violence Resource Center, Statistics About Sexual Violence, http://www.nsvrc.org/sites/default/files/publications_nsvrc_factsheet_mediapacket_statistics-about-sexual-violence_0.pdf, (citing C.A. Rennison, Rape and sexual assault: Reporting to police and medical attention, 1992-2000

[NCJ 194530] (2002), retrieved from the Bureau of Justice Statistics, U.S.

Department of Justice, http://bjs.ojp.usdoj.gov/content/pub/pdf/rsarp00.pdf).

${ }^{69}$ KRAKAUER, supra note 9 , at 266.

${ }^{70} \mathrm{Id}$. 
"I am so sorry. I should have taken better care of you" "71 — reasonably indicating that there were demonstrable signs of assault prompting such an apology. In this case, which involved an alleged gang rape, a detective downloaded all of the survivor's text messages, including the one from her friend, and submitted them as evidence to the prosecutor, who nevertheless declined to bring a charges. ${ }^{72}$

By contrast, higher education institutions are required to conduct thorough investigations, and to do so immediately ${ }^{73}$ theoretically giving these investigators access to communications sooner than police would otherwise have access, when information is more accurate and able to paint a more complete picture of the events. However, if campus investigators are not comprehensive with their gathering of electronic communications, and instead only gather communications from the survivor, the campus investigation could make eventual prosecution more difficult because it opens up more opportunities to distort the survivor's electronic communications using rape myths, without possible corroborating evidence from others. Kelly Alison Behre recounts a case from a student survivor which demonstrates the risk a survivor takes in sharing electronic communications.

Two weeks later, the college administrator investigating the case contacts the student again and lets her know that she has spoken with the assailant and scheduled meetings with his witnesses. The administrator explains that she will need to interview the student again. She also asks the student to bring her cell phone to her office so she can see the text messages, since the assailant claims there are text messages proving his innocence. The student complies, and the administrator downloads all of her texts onto a computer. The student explains her concern that the assailant will be able to see all of her personal communications from the past year. The administrator says she is sympathetic but that the assailant has the right to view all of the evidence used in the investigation. The student later learns the assailant and his attorney were allowed to view and make hand copies of all of her text messages. $^{74}$

\footnotetext{
${ }^{71} I d$. at 43 .

${ }^{72} I d$.

${ }^{73}$ See supra Section IV.

${ }^{74}$ Kelly Alison Behre, Ensuring Choice and Voice for Campus Sexual Assault Victims: A Call for Victims' Attorneys, 65 DraKe L. REV. 293, 302-03 (2017). The attorney, however, "was not allowed to take the student's cell phone to a forensic specialist nor provided with access to her laptop or cloud account." Id. at 306.
} 
In cases such as this, ensuring that survivors have advocates and guidance about the investigatory process will be crucial to ensuring that electronic communications serve to facilitate a fairer investigation, rather than harm the survivor. As Behre explains, "victims' attorneys can assist students in developing the type of evidence that might further their case, such as text messages, social media posts, witnesses, and medical records, while advising them about weighing their privacy interests against their interests in forwarding the campus investigation before submitting specific evidence." ${ }^{, 75}$ The importance of these considerations is heightened because campuses are increasingly sharing information from their investigations with local law enforcement, ${ }^{76}$ including through formal memoranda of understanding, which were advocated for by the Obama Administration in its 2015 White House Task Force on Protecting Students. ${ }^{77}$

There are additional challenging realities of the Title IX setting that must be overcome for these opportunities to lead to any kind of sustainable progress. Few students report sexual assault to either police or campus officials, ${ }^{78}$ and if reported to the school, there are disincentives to find in favor of the survivor. ${ }^{79}$ In cases where an assault is reported to a Title IX office, some schools will mishandle an investigation, or even fail to conduct one in the first place. One need look no further than the list of schools being investigated for improper handling of complaints by students under Title IX - a list that in 2017 has reached as high as $351^{80}$ - to see that handling of these cases is far from perfect. The Trump Administration's recent revocation of the Obama Administration's Title IX guidance ${ }^{81}$ threatens to remove

\footnotetext{
${ }^{75} \mathrm{Id}$. at 335 .

${ }^{76}$ See Veidlinger, supra note 3, at 20-21.

${ }^{77}$ White House Task Force ON Protecting Students, BuILding Partnerships AMONG LAW ENFORCEMENT AgENCIES, COLLEGES AND UNIVERSITIES: DEVELOPING A MEMorandum of Understanding to PREVEnT AND RESPOND EFFECTIVEly to SeXual Assaults at Colleges AND Universities (Jan. 2015).

78 "By one estimate, only about $12 \%$ of persons who experience sexual assault report it to police or campus officials." Brake, supra note 41, at 34-35, citing Dean G. Kilpatrick et al., Drug-facilitated, Incapacitated, and Forcible Rape: A National Study, 3 Med. U. of S.C., NAT'L CRime Victims Res. \& Treatment CtR. (2007) ("Among college women, about $12 \%$ of rapes were reported to law enforcement.").

${ }^{79}$ Brake, supra note 42, at 35 ("Commentators have noted ... [that] incentives placed on institutions in adjudicating sexual assault tend to align against a university finding that an accused student is responsible.") (citing Jennifer McErlean, Sexual Assault in Principle and in Practice, in CAMPUS Action AgAINST SEXUAL

Assault: Needs, Policies, Procedures, and Training Programs 83, 85-86).

${ }^{80}$ See The Chronicle OF Higher EdUCATION, Title IX: Tracking Sexual Assault Violations, https://projects.chronicle.com/titleix/ (last visited Nov. 17, 2017).

${ }^{81}$ See Anderson, supra, note 44.
} 
important oversight of schools' obligations and create a false sense that schools are properly addressing sexual assault on campus.

Moreover, to the extent that institutions do continue to conduct investigations and hearings, there is always a risk that campus investigators and/or decision makers will succumb to rape myths when an opportunity is presented by an electronic communication or other piece of evidence. Such perpetuation at the campus level is especially dangerous because it reinforces inequality, not to mention the harm to the individual survivor. ${ }^{82}$ An institution's failure to fairly and effectively utilize electronic communications in instances where they have access to them, could exacerbate the very problems Title IX was designed to combat.

One way to begin overcoming these challenges is to leverage campus resources to educate Title IX investigators, decision makers, and advocates, who are positioned within the Title IX setting much more favorably than jurors are in the criminal setting, to accept the science and reject the rape myths that are frequently implicated by electronic communications.

\section{LEVERAGE BETTER-SITUATED DECISION MAKERS OPERATING UNDER A LOWER BURDEN OF PROOF}

As a general matter, there are several reasons why Title IX decision makers are less likely than jury members to be susceptible to the two previously identified vulnerabilities of electronic communications in sexual assault investigations: (1) that some decision makers do not understand, do not believe, or are not open to considering the science behind survivor responses to trauma-including a desire to maintain normalcy, which are increasingly visible due to electronic communications, and (2) that some decision makers do not understand the way college students communicate through technology, and therefore do not understand the underlying normalcy that trauma survivors try to maintain vis-à-vis that technology following an assault. As members of academic institutions, Title IX decision makers should, at least in theory, be open to the scientific method that underlies academic studies explaining trauma response. This being said, the generational gap between decision makers and the students involved, might present challenges when it comes to understanding the

\footnotetext{
${ }^{82}$ Brake, supra note 42, at 34 (“An educational institution's lackluster response once a sexual assault has occurred compounds the harm of the initial assault, especially when persons within the institution respond in ways that neutralize sexual misconduct.") (citing C.P. Smith \& J.J. Freyd, Dangerous Safe Havens: Institutional Betrayal Exacerbates Sexual Trauma, 26 J. TRAUMATIC STRESS 119, 119-20 (2013)).
} 
technology involved, in the same way that they would for the general public. Even so, Title IX decision makers work in a setting designed to serve students, and are better situated to learn and understand their communication habits, including the technologies they use.

In addition, campus Title IX investigations and hearings are conducted internally and do not involve members of the public. By contrast, jury trials involving cases where a university or college is involved can expose tension between the campus and members of the community that are not affiliated with the school. If leveraged by defense attorneys, as was the case in Missoula, the tensions might cause a jury to rule against the side it associates with the academic institution, thereby serving as another tool to discredit academic explanations of trauma, while encouraging explanations based in rape myths.

One type of tension could be described as an ingrained hostility toward academia. The Johnson verdict was not reached in a vacuum as the result of deeply held (or even subconscious) belief by the jury in rape myths, or fundamental opposition to science and understanding technology - though ingrained beliefs might have played a role. Rather, rape myths and rape culture were a central component of the defense's case, and were the lens through which the defense urged the jury to view the case, discrediting any explanation of events that could be characterized as "academic." Indeed, Krakauer recounts that during closing arguments, defense counsel "asked the jury, once again, to ponder Washburn's seemingly inexplicable behavior immediately after she was allegedly raped ...." ${ }^{83}$ Rather than offer scientific evidence that countered that of Lisak's, defense counsel chose to delegitimize Lisak as an elite academic outsider, stating to the Montana jury, "This is all the stuff that they need the Boston expert to explain ... [but] [t]he truth does not require an explanation." ${ }^{, 84}$

The way this defense played out is not uncommon in the criminal setting. Defense attorneys, like all attorneys, have an ethical obligation to zealously advocate for their clients ${ }^{85}$ within the bounds of the rules of the court and the lawyer's ethical obligations under their jurisdiction's rules of professional conduct. It is beyond the scope of this paper to address whether the perpetuation of rape myths, including by distorting the meaning behind electronic communications, violates a lawyer's ethical obligations, such as the obligation to be candid with a tribunal. ${ }^{86}$ In any event, attempting to discredit expert testimony has

\footnotetext{
${ }^{83}$ KRAKAUER, supra note 9, at 295.

${ }^{84} \mathrm{Id}$.

${ }^{85}$ See Model Rules of Prof'L CONDUCT r. 1.3 (Am. BAR AsS'N).

${ }^{86}$ See Model Rules of Prof'L Conduct r. 3.3 (Am. BAR Ass'N).
} 
long been a common method of advocacy, including in sexual assault cases. ${ }^{87}$

In urging the jury not to accept Lisak's scientific explanations, the defense created - or to the extent that it already existed, fueled - an ingrained hostility against academic institutions and its members and methods. This is a particularly potent tool in college towns, where examples of such hostility have been well documented. ${ }^{88}$ Although Lisak was not a member of the faculty of the University of Montana (he is faculty at Harvard), his presence and mission in the college town was painted as condescending, paternalistic, and insulting to community members who might have harbored some ingrained hostility toward academic institutions and their members if they felt ostracized by the university ${ }^{89}$ If jurors did not already harbor these feelings, they might well have by the end of the trial.

Another type of tension could be described as prideful resentment. To the extent that non-university affiliated members of a college community do have pride in their local institution, Missoula demonstrates that this pride, too, can be used as a tool to favor the defense's interpretation of electronic communications. When, as is often the case, such pride involves the university's athletics program, an institution's response to sexual assault perpetrated by an athlete- such as expelling the student athlete - can fuel resentment among the local fan base. In many college towns, community members who are otherwise unaffiliated with the university make the university's athletics program a strong part of their individual and collective identity. It is not uncommon for this pride to manifest itself in the form of large-scale victim blaming when the accused is a member of the school's football

\footnotetext{
${ }^{87}$ See Long, Palmer \& Thome, supra note 15, at 569.

${ }^{88}$ For example, BREAKING AwAY (Twentieth Century Fox Film Corporation 1979). The Academy Award Nominated Film Breaking Away, set in Bloomington, Indiana, home of Indiana University, depicted tension between students at the university and non-student members of the community whom students called "Cutters"-a derogatory term for those who performed the manual labor of cutting limestone in the local quarries. The tension from the non-university affiliated population stemmed from both structural exclusion (e.g. the main character's father helped build the university's library, but was not allowed to use it) and overt social rejection (depicted in the film by many verbal and physical assaults leveled at the "Cutters" by the students).

${ }^{89}$ KRAKAUER, supra note 9, at 295.
} 
team.${ }^{90}$ In Missoula, Montana, the community is known as Griz Nation, for the University of Montana Grizzly football team. ${ }^{91}$

Although the university itself is not part of the prosecution in trials against university athletes, trials often take place after an institution has completed its Title IX investigation. In the case of Jordan Johnson, the response of Griz Nation to the university's decision to expel Johnson was nothing short of collective outrage, ${ }^{92}$ a sentiment that the defense seized on and exploited during the case. And although universities and prosecutors are not formally affiliated, they are becoming more closely associated through the adoption of memoranda of understanding, through which schools and local police departments agree to share information, including copies of electronic communications, all of which could eventually aid the prosecutor. ${ }^{93}$ This could lend some support to a defense narrative that a prosecutor and university are "on the same side," and undermine efforts to explain the science behind survivor trauma and use of electronic communications in an "academic" fashion, either generally or by leveraging findings from an earlier Title IX investigation.

These tensions that manifest among juries made up of community members are not overtly present in the same way in Title IX investigations themselves, in which advocates and decision makers are largely university employees. This presents one less avenue for decision makers in the Title IX setting to discredit science in favor of rape myths. The tension may, however, manifest in the Title IX setting in the form of political and economic pressure from the larger community if action against a student athlete would affect the success and public support of a high-profile athletics program. Moreover, there is no guarantee that decision makers in the Title IX setting will not succumb to rape myths that already predominate society, even absent tension or aggressive advocates for the accused.

Part of ongoing educational campaigns regarding rape myths in the college campus setting must include educating those involved in Title IX investigations. Because the Title IX setting largely utilizes, at least for now, a lower standard of proof than the criminal setting, institutions might have more latitude to apply scientific findings to cases involving assault than in the criminal setting. Although science

\footnotetext{
${ }^{90}$ See, e.g., Jeff Andrews, Tennessee Fans Blame Rape Victims for Messing Up Football, VoCATIVE (Feb. 11, 2016), http://www.vocativ.com/283331/tennesseefans-blame-rape-victims-for-messing-up-football/index.html.

${ }^{91}$ See, e.g., 2008 University of Montana Football stadium introduction video, https://www.youtube.com/watch?v=1qI59WQ9n6U (ending with text declaring “This Is Griz Nation.").

${ }^{92}$ Id. at $183-87$.

${ }^{93}$ See White House Task Force on Protecting Students, supra note 78.
} 
regarding trauma response has been around for quite some time, ${ }^{94}$ the role of technology in the daily lives of college students changes rapidly. Operating under a lower burden of proof could help facilitate a more reasoned examination of these issues, to the benefit of society.

As communications technologies advance rapidly, large segments of the public do not keep up. ${ }^{95}$ At the current rate of new deployments, there will always be some degree of uncertainty regarding these new technologies and the underlying social behaviors of those that use them, just by virtue of these forms of communication being new. Under the criminal standard, this uncertainty can be channeled by defense attorneys into creating reasonable doubt. One reason to retain Title IX's lower standard is that it allows more room for some degree of the inevitable uncertainty that accompanies new technologies, in a setting where those technologies are adopted at high rates. This disarms to some degree the power of isolated communications that can be twisted and explained in a distorted fashion using rape myths, enabling a more complete examination of all communications gathered surrounding the events in question.

\section{CONCLUSION}

To capitalize on these opportunities, campus investigators and decision makers must overcome the challenges identified in this essay. Any improved processes and outcomes in the Title IX setting will not automatically translate to the criminal setting, which has different goals and different corresponding processes. However, the ability to paint a more complete picture with greater access to electronic communications, and being favorably situated to foster scientific acceptance and technological understanding, could enable the Title IX setting to play a role in influencing subsequent criminal trials, including by causing a more complete picture being shared with police pursuant to memoranda of understanding. If these findings eventually make their way into the courtroom, they might be more likely to withstand efforts to weaponized rape myths. Other efforts should include educating advocates, administrators, and the broader community about rape myths, survivor trauma, and communications technologies and how they are accessed and used by different generations. This analysis captures only a small portion of the efforts needed to combat broader rape culture, and depends on continued Title IX enforcement and oversight in the face of the Trump Administrations efforts to weaken federal guidance and oversight. If campuses can overcome the

\footnotetext{
${ }^{94}$ See Sanday, supra note 52.

${ }^{95}$ See Wakefield, supra note 22.
} 
challenges and embrace the opportunities identified in this essay by making fairer use of electronic communications, it could prove to be a helpful tool in making progress on these important fronts throughout the criminal justice system and in society. 